\title{
Enzyme immunoassays for total and allergen specific IgE in population studies
}

\author{
Gert Doekes, Jeroen Douwes, Inge Wouters, Siegfried de Wind, Remko Houba, \\ Albert Hollander
}

\begin{abstract}
Objective-Extensive IgE serology in occupational or environmental health studies is often hampered by a lack of technical facilities and finance. The use in population studies of relatively simple and inexpensive enzyme immunoassays (EIAs) was therefore evaluated for the assessment of total serum immunoglobulin $E$ (IgE), and of specific IgE reactions with various common (house dust mites, grass and birch pollen, and cat) or occupational (fungal $\alpha$-amylase and rat urinary protein) allergens.
\end{abstract}

Methods-Total IgE was measured with a sandwich EIA, calibrated with commercially available IgE standards. Reproducibility was studied by testing pooled normal human serum samples in each of a large series of test plates. A panel of 156 children's serum samples with known IgE values was used to compare the assay with other total IgE assays. A previously developed EIA for anti-yeast IgE was adapted for the measurement of IgE reacting with various common and occupational allergens. Binding of IgE to microwells coated with commercially available allergen extracts, or allergen preparations from our own laboratory, was measured with a monoclonal antihuman IgE antibody and subsequent incubations with biotinylated rabbit antimouse Ig and avidin-peroxidase. Panels of serum samples from school children (n $=116)$, bakery workers $(n=126)$, and laboratory animal workers $(n=52)$ were used to study sensitivity and specificity, with reference to skin prick tests as the standard, and to compare the EIAs with commercially available test kits.

Results-The detection limit of the EIA for total IgE was 0.5-1 kU/h for undiluted serum samples, and the coefficient of variation between assays was less than $15 \%$ at serum concentrations between 1 and $150 \mathrm{kU} / 1$. Results obtained with the panel of 156 children's serum samples were strongly correlated $\left(r^{2}=0 \cdot 86\right)$ with IgE concentrations measured previously by radioimmunoassay. The results of the EIA for various occupational allergens correlated very well, both qualitatively and quantitatively, with the results of commercial test kits. Sensitivity and specificity of the EIA results as a predictor of skin prick test reactivity towards common allergens (house dust mite, grass pollen, birch pollen, and cat) were remarkably high $(>80 \%-90 \%)$ in the series of 116 children's serum samples. In a population of bakery workers the specificity of the EIAs was also very high (>90\%). The sensitivity was notably lower $(30 \%-70 \%)$ in this adult population, which is, however, in agreement with results reported for conventional IgE tests.

Conclusion-As the costs were estimated to be at least five to 10 -fold lower than those of commercial test kits, the EIAs for total and specific IgE may be very useful tools in epidemiological studies of atopic respiratory or other disorders.

(Occup Environ Med 1996;53:63-70)

Keywords: immunoglobulin E; atopy; enzyme immunoassay; occupational allergy

Atopy, defined as the presence of immediate type (type I) skin or bronchial hyperreactivity to specific allergens, is a major determinant in several occupational or environmentally induced respiratory disorders. Immediate type reactivity results from a preceding atopic immune response in which production of specific IgE antibodies is initiated and maintained by repeated or prolonged contact with the allergen. Thus, occupational diseases like baker's asthma or respiratory allergy to laboratory animals are presumably due to atopic sensitisation to inhaled proteins from flour dust or rodents' urinary proteins, respectively. ${ }^{1-5}$ Similarly, atopic sensitisation and exposure to indoor allergens from house dust mites or pet animals are closely associated with the development of extrinsic asthma and other respiratory allergies, ${ }^{6-9}$ which therefore might be considered as environmentally-induced disorders. In all cases of symptomatic type I respiratory allergy, aeroallergen exposure is presumed to cause both atopic sensitisationthe production of specific IgE antibodies-and the induction of respiratory symptoms in sensitised people. Allergen specific IgE may thus function in population studies as an effect variable, or as a risk factor for developing respiratory or other health complaints. Enhanced total serum IgE might also indicate a person's atopic state or predisposition, ${ }^{10-13}$ and thus identify people at high risk of developing allergic disease.

Total and allergen specific serum IgEs are usually measured with commercially available immunoassays, with cellulose discs, magnetic 
beads, or other carriers to which the allergens have been coupled by the manufacturer. Such test kits are well adapted to the demands of clinical diagnostic laboratories, but may have several disadvantages in population studies, including a lack of flexibility (if unknown preparations or dust extracts have to be tested as potential sources of allergen) and the relatively high costs. In this report we describe the use of a previously developed enzyme immunoassay (EIA) for yeast specific $\operatorname{IgE}^{1415}$ for the detection of serum IgE that reacts with common allergens like house dust mites, pollens, cat dander, and various occupational allergens. Thus, the same materialsmicrotitre plates, immune reagents, assay buffers, etc-and assay procedures were used, except that the microplates were coated with either commercially available allergen extracts, or our own allergen preparations. The tests were validated with serum panels obtained in our ongoing environmental or occupational health studies. All serum samples came from people for whom the results were available from previous in vivo (skin prick test) or in vitro (radioallergosorbent test (RAST)) type I allergy tests to common and occupational allergens. Together with a simple and inexpensive sandwich EIA for total serum IgE the assays seemed to be very useful tools for the serological identification and characterisation of atopic subjects in population studies.

\section{Materials and methods}

MATERIALS AND REAGENTS

Assays were performed in flat bottomed 96 well polystyrene microtitre plates with high binding capacity (Product No 655061; Greiner, Nuertingen, Germany). Monoclonal mouse anti-human IgE (No M 1294; Central Laboratory of the Red Cross Blood Transfusion Service (CLB), Amsterdam, The Netherlands) and a peroxidase conjugate prepared from the same antibody (No M 1334 CLB), biotinylated affinity purified rabbit anti-mouse Ig (No E 354; Dakopatts (DAKO), Copenhagen, Denmark), avidin peroxidase conjugate (No P 364; DAKO), gelatin (Merck, Darmstadt, Germany) Tween-20 (Polysorbatum; Merck), $o$ phenylenediamine (No $P$ 1526; Sigma Chemicals, St Louis, MO, USA), and $\mathrm{H}_{2} \mathrm{O}_{2}$ (Merck, Darmstadt, Germany), were purchased as indicated.

\section{ALLERGENS}

Preparations of common allergens were obtained as lyophilised extracts from ALK Benelux (Houten, The Netherlands): house dust mite (Dermatophagoides pteronyssinus, Product No SQ 503); grass pollen (Lolium perenne, SQ 223; and Dactylis glomerata, SQ 214); birch pollen (Betula verrucosa; SQ 108); and cat (SQ 555). These extracts are the same as used by ALK Benelux for the production of skin prick test solutions. As occupational allergens, rat and mouse urinary proteins and fungal $\alpha$-amylase were tested. Rat and mouse urinary allergen preparations were produced by ALK
Benelux from large batches of rat (Wistar) and mouse (Balb/c) urine. Both were a mixture of urine collected at two different animal laboratories, from both young and old, and male and female animals. Proteins were isolated by extensive dialysis against phosphate buffered saline and bidest, and concentrated by lyophilisation. The same preparations were used for skin prick tests to assess sensitisation among laboratory animal workers (Hollander et al, personal communication). A semipurified preparation of $\alpha$-amylase from Aspergillus oryzae (Fungamyl (Novo Nordisk, Denmark)) was kindly provided by Dr L Belin, Göteborg.

Stock solutions of these allergens, prepared by dissolving lyophilised extracts at $1 \mathrm{mg} / \mathrm{ml}$ in fresh phosphate buffered saline (PBS; $\mathrm{pH}$ $7 \cdot 0-7 \cdot 4$ ) could be stored at $-20^{\circ} \mathrm{C}$ for several months without substantial loss of allergenic activity. In this study, however, new stock solutions were prepared weekly.

\section{EIA FOR TOTAL IgE}

All incubations in the assays for total or specific IgE were performed with $0.1 \mathrm{ml}$ aliquots, and each incubation was followed by extensive washing - three cycles on an automatic plate washer (LKB-Pharmacia) with PBS containing $0.05 \%(\mathrm{v} / \mathrm{v})$ Tween-20. Coating was performed in PBS, and serum samples, immune reagents, and peroxidase conjugates were diluted and incubated in Tween-20 with $0.5 \%$ (w/v) gelatin.

Total IgE was measured in microwells coated overnight at $4^{\circ} \mathrm{C}$ with mouse monoclonal anti-IgE (1/4000 in PBS). Human serum samples were routinely added at dilutions $1 / 10,1 / 20,1 / 40$, and $1 / 80$ in Tween-20 with gelatin, and incubated for two hours at $37^{\circ} \mathrm{C}$. Binding of IgE to the wells was measured by incubation for one hour at $37^{\circ} \mathrm{C}$ with peroxidase labelled mouse monoclonal antiIgE (1/1000), followed by an incubation of 30 minutes, at $20^{\circ} \mathrm{C}$ and in the dark, with $o$ phenylenediamine $(2 \mathrm{mg} / \mathrm{ml})$ in $0.05 \mathrm{M}$ citrate/phosphate buffer, $\mathrm{pH}$ 5.5, containing $0.015 \% \mathrm{H}_{2} \mathrm{O}_{2}$. The enzyme reaction was ended by adding $0.05 \mathrm{ml} 2 \mathrm{~N} \mathrm{HCl}$, and the optical density was read at $492 \mathrm{~nm}$.

The assay was calibrated with reference preparations for total $\operatorname{IgE}(1000$ and 2000 $\mathrm{kU} / \mathrm{l}$ ) from Kabi-Pharmacia (No 10-9123$01)$. In each microtitre plate serially diluted reference samples were included and a calibration line was obtained for IgE concentrations ranging from 0.05 to $10 \mathrm{kU} / 1$. These calibration lines, and the dose-response curves for serum samples showed a linear relation between concentration and optical density up to optical density values $>2.0$ (fig 1 ) Concentrations of IgE in test samples were therefore measured by direct interpolation of the observed optical density on non-transformed calibration lines, provided that the optical density values were in the range between the mean ( $3 \mathrm{SDs}$ ) of the reagent blank (no serum control), and an upper limit of 2.5 . When the results of more than two serum dilutions did not meet these criteria because the IgE concentration was too high 
the test was repeated at higher serum dilutions. Tests were also repeated if results obtained at different serum dilutions differed by more than $15 \%$.

EIA FOR ALLERGEN SPECIFIC IgE

Specific IgE was measured with the modified EIA method used previously in studies on anti-yeast allergy. ${ }^{14}{ }^{15}$ Microwells were coated overnight at $4^{\circ} \mathrm{C}$ with allergen extracts in PBS, at concentrations varying from 10 to $50 \mu \mathrm{g} / \mathrm{ml}$, depending on the allergen. Serum samples were incubated for two hours at $37^{\circ} \mathrm{C}$, either at one dilution (usually $1 / 10$ ), or at $1 / 5,1 / 10$, and $1 / 20$ in Tween-20 with gelatin. Bound IgE was measured with a sensitive four step procedure, consisting of three one hour incubations at $37^{\circ} \mathrm{C}$ with $(a)$ monoclonal mouse anti-IgE $(1 / 16000) ;(b)$ affinity purified, biotinylated rabbit anti-mouse Ig (1/2000); (c) avidin peroxidase (1/2000); and (d) an incubation for 30 minutes with optical densities as described for the EIA for total IgE.

\section{SERUM SAMPLES}

Pooled normal human serum-a mixture of serum samples from at least 200 healthy blood donors from several European countries (Precinorm; Boehringer, Mannheim, Germany) - was used as an additional reference preparation to test the reproducibility of the EIA methods. Test serum samples were derived from several epidemiological research projects on the relation between exposure to indoor allergens and the occurrence of respiratory disorders. From a study on respiratory allergy among bakery workers ( $\mathrm{R}$ Houba et al, personal communication), 126 serum samples were selected: 117 serum samples from subjects with at least one positive skin prick test in a panel of common allergens, and nine serum samples from subjects with all skin tests negative. A second large serum panel consisted of 116 serum samples from $6-12$ year old school children participating in a study on acute respiratory effects of winter smog episodes and selected because of the presence $(n=57)$ or absence $(n=59)$ of at least one positive answer in a standard questionnaire on respiratory symptoms. ${ }^{16}$ For the comparison of the EIA for total IgE with another assay, total IgE was measured in 156 serum samples from school children participating in a previous project on the relation between indoor exposure to allergens and respiratory complaints. ${ }^{17}$ Total IgE had been measured in these serum samples by radioimmunoassay at the Department of Allergy of the CLB, Amsterdam (Professor Dr RC Aalberse, Dr S Stapel). Other serum samples used in this study came from 52 laboratory animal workers tested both in vivo (skin prick test) and in vitro (AlaSTAT, DPC) for type I allergy to rat urinary proteins, and 32 bakery workers tested by skin prick test and Phadezym RAST for type I reactivity to fungal $\alpha$-amylase.

Skin prick tests had been performed with panels of common allergens, including house dust mites (ALK No SQ 503), grass pollen (ALK No SQ 293), tree pollen (ALK No SQ
197), and cat allergens (ALK No SQ 555). Positive reactions were defined as a weal size $\geqslant 3 \mathrm{~mm}$ larger than that of the negative control.

Results

TOTAL IgE

Figure 1 shows the dose-response curves for eight serum samples with varying total IgE concentrations, together with the calibration line of the same day. The detection limit for the diluted standard seemed to be about $0.05-0 \cdot 1 \mathrm{kU} / 1$. Titration curves for practically all serum samples were parallel to the standard curve, up to optical density values of $>2 \cdot 0$, provided that the serum samples were diluted at least 10 times; at higher concentrations some serum samples showed a decreased slope, and concentrations calculated from $1 / 5$ dilutions thus systematically underestimated the real serum IgE content (not shown). We therefore routinely test serum samples in four dilutions $(1 / 10,1 / 20,1 / 40$, and $1 / 80)$, and thus the detection limit for undiluted test serum samples is $0.5-1 \mathrm{kU} / \mathrm{l}$. On the other hand, maximum optical density values that can be reliably read $(2 \cdot 0-2 \cdot 5)$ are usually reached at a standard concentration of about 3-5 kU/l, which means that in principle the upper limit for undiluted serum samples is $300-400 \mathrm{kU} / 1$. Our standard protocol requires that for each serum sample at least two dilutions give optical density values in the working range between 0.1 and 2.5 , and therefore in practice the upper limit for undiluted serum samples is $150-200 \mathrm{kU} / 1$. In this way, all serum samples with total IgE in the normal range $(<150 \mathrm{kU} / \mathrm{l})$ should give reliable values in the first test.

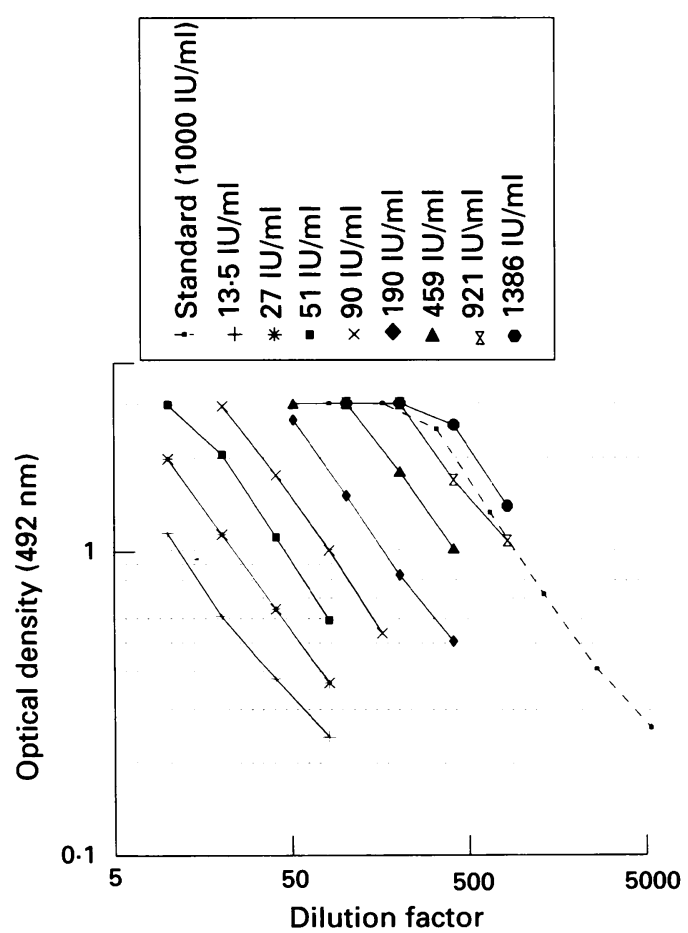

Figure 1 Dose-response curves for eight serum samples and the IgE reference preparation in the EIA for total IgE. 


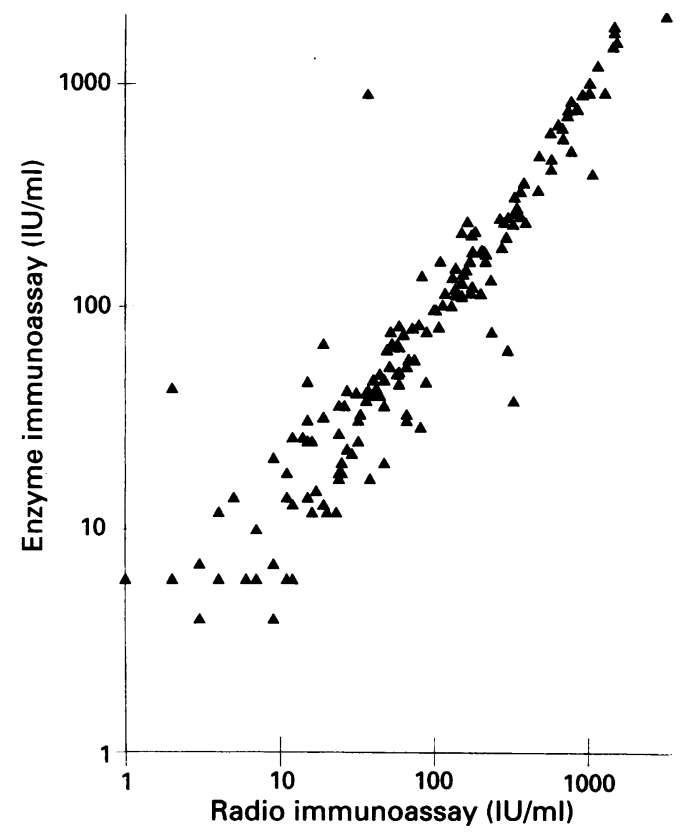

Figure 2 Correlation between total IgE concentrations measured by RIA or by the sandwich EIA in 156 serum samples from 6-12 year old school children; $r^{2}$ for log transformed values $=0 \cdot 86$.

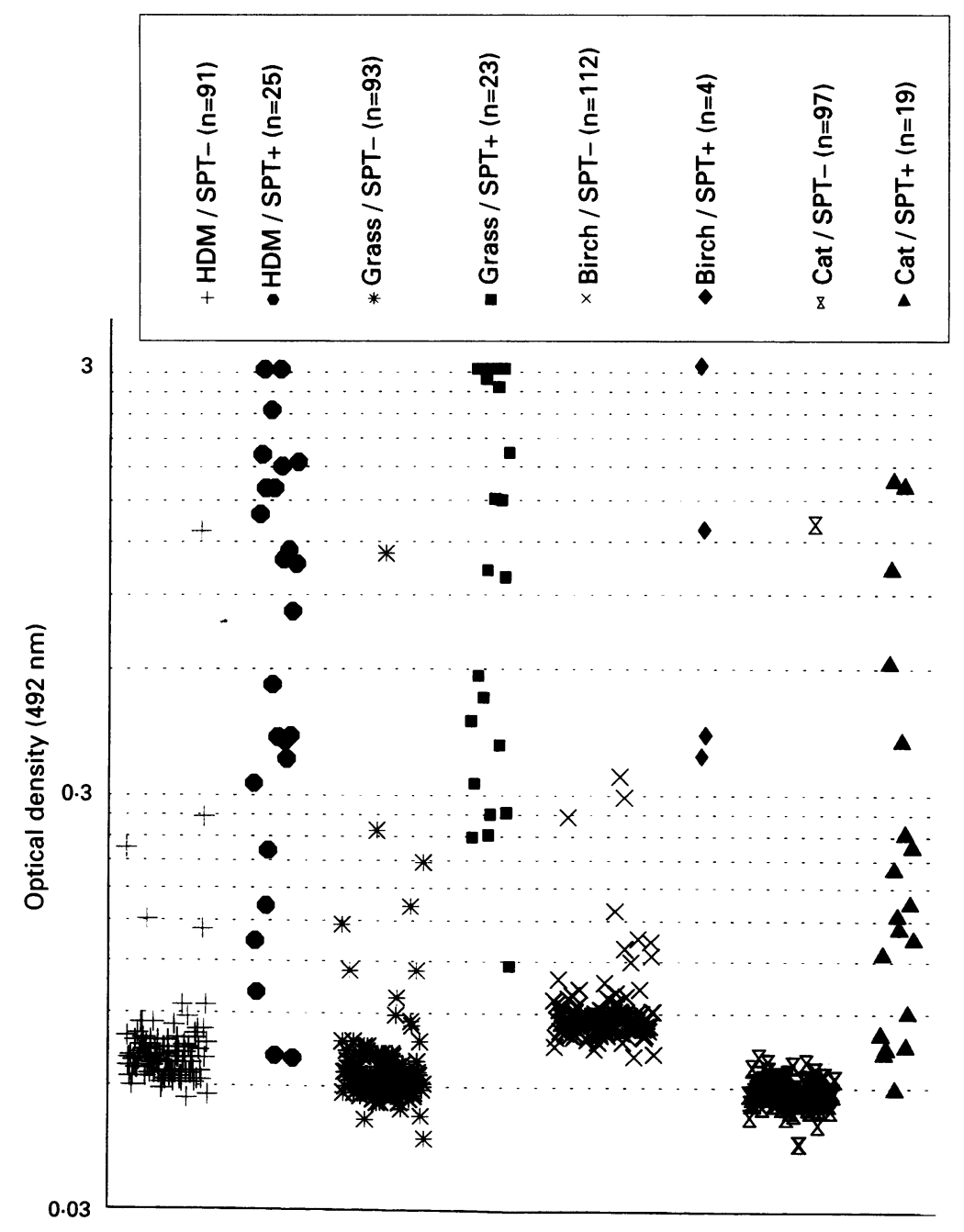

Figure $3 E I A$ for specific IgE to common allergens house dust mite (HDM), grass pollen, birch pollen, and cat, in 116 serum samples from school children. Results are shown separately for subjects with a negative or positive skin prick test (SPT) for the corresponding allergen.
In $\log \log$ plots the slopes of all curves, including that of the standard, were close to $1 \cdot 0$, thus confirming the linearity of the doseresponse relation. Accordingly, results obtained with different dilutions of the same serum samples usually differed by less than $10 \%$, if the corresponding optical density values were between $0 \cdot 1$ and $2 \cdot 5$. Total serum IgE concentrations below $1 \mathrm{kU} / 1$ were very rare, and serum samples with concentrations of more than $150-200 \mathrm{kU} / \mathrm{l}$ were retested at higher dilutions, starting at 1/50 when the optical density obtained at $1 / 80$ was $<3 \cdot 0$, and at $1 / 100$ for the other strongly reactive serum samples. Thus serum samples with total IgE up to $4000 \mathrm{kU} / 1$ can give reliable data for at least two serum dilutions.

Comparison of the dose-response curves of the calibration standard in a large series of microtitre plates (89 plates on 11 days) showed relatively small differences between different plates of the same day, with optical density values usually differing by $<10 \%$ at concentrations of $0.5-4 \mathrm{kU} / 1$, whereas the differences between the mean calibration curves of different days were somewhat larger, with a mean coefficient of variation of $15 \%-20 \%$ for (averaged) optical density values of the various IgE concentrations. The influence of this day to day variance was effectively eliminated by interpolation of the optical density values for individual (diluted) serum samples on the calibration line for the same test plate; essentially identical results were obtained if the mean calibration line of the same day was used. Thus, commercially available pooled normal human serum samples, which were routinely included as positive controls in each test plate, showed a mean (SD) IgE concentration of 20.08 $(2.41) \mathrm{kU} / 1$ in the series of 89 test plates already mentioned. In another series of 10 plates on three different days the same serum pool showed mean values of $22.3,19.7$, and $21.1 \mathrm{kU} / 1$, with within day and between plate coefficients of variation of $14.9 \%, 7 \cdot 5 \%$, and

Table 1 Reproducibility of the EIA for specific IgE: comparison of two thresholds for a positive reaction: all serum samples with a reaction above the lower threshold in the first test series, and a randomly selected number of negative serum samples were retested: numbers of concordant $(+1+$ and $-1-)$ and discordant $(+1-$ and $-1+$ ) results are given for the four common allergens. Samples were tested on both occasions at a 1/10 dilution

\begin{tabular}{|c|c|c|}
\hline Allergen & Lower threshold* & Higher threshold $\uparrow$ \\
\hline $\begin{array}{l}\text { House dust mite } \\
\qquad(\mathrm{n}=56)\end{array}$ & $\begin{array}{lr}+1+ & 31 \\
-1- & 7 \\
+/- & 18 \\
-1+ & 0\end{array}$ & $\begin{array}{rr}+l+ & 26 \\
-1- & 29 \\
+1- & 1 \\
-1+ & 0\end{array}$ \\
\hline $\begin{array}{l}\text { Grass pollen } \\
(n=43)\end{array}$ & $\begin{array}{lr}+l+ & 32 \\
-l- & 6 \\
+l- & 5 \\
-l+ & 0\end{array}$ & $\begin{array}{lr}+l+ & 29 \\
-l- & 10 \\
+l- & 1 \\
-l+ & 1\end{array}$ \\
\hline $\begin{array}{l}\text { Birch pollen } \\
\quad(\mathrm{n}=20)\end{array}$ & $\begin{array}{ll}-1+ & 0 \\
+1+ & 9 \\
-1- & 8 \\
+1- & 3 \\
-1+ & 0\end{array}$ & $\begin{array}{lr}-l+ & 0 \\
+/+ & 8 \\
-l- & 12 \\
+/- & 0 \\
-/+ & 0\end{array}$ \\
\hline $\begin{array}{l}\text { Cat } \\
\quad(n=28)\end{array}$ & $\begin{array}{lr}+l+ & 13 \\
-l- & 15 \\
+/- & 0 \\
-l+ & 0\end{array}$ & $\begin{array}{lr}+l+ & 13 \\
-l- & 15 \\
+l- & 0 \\
-1+ & 0\end{array}$ \\
\hline
\end{tabular}

${ }^{\star}$ Low threshold value $=$ mean optical density ${ }_{492}+3$ SDs of the reagent blank; thigh threshold value $=$ mean optical density ${ }_{492}$ (reagent blank) +0.05 


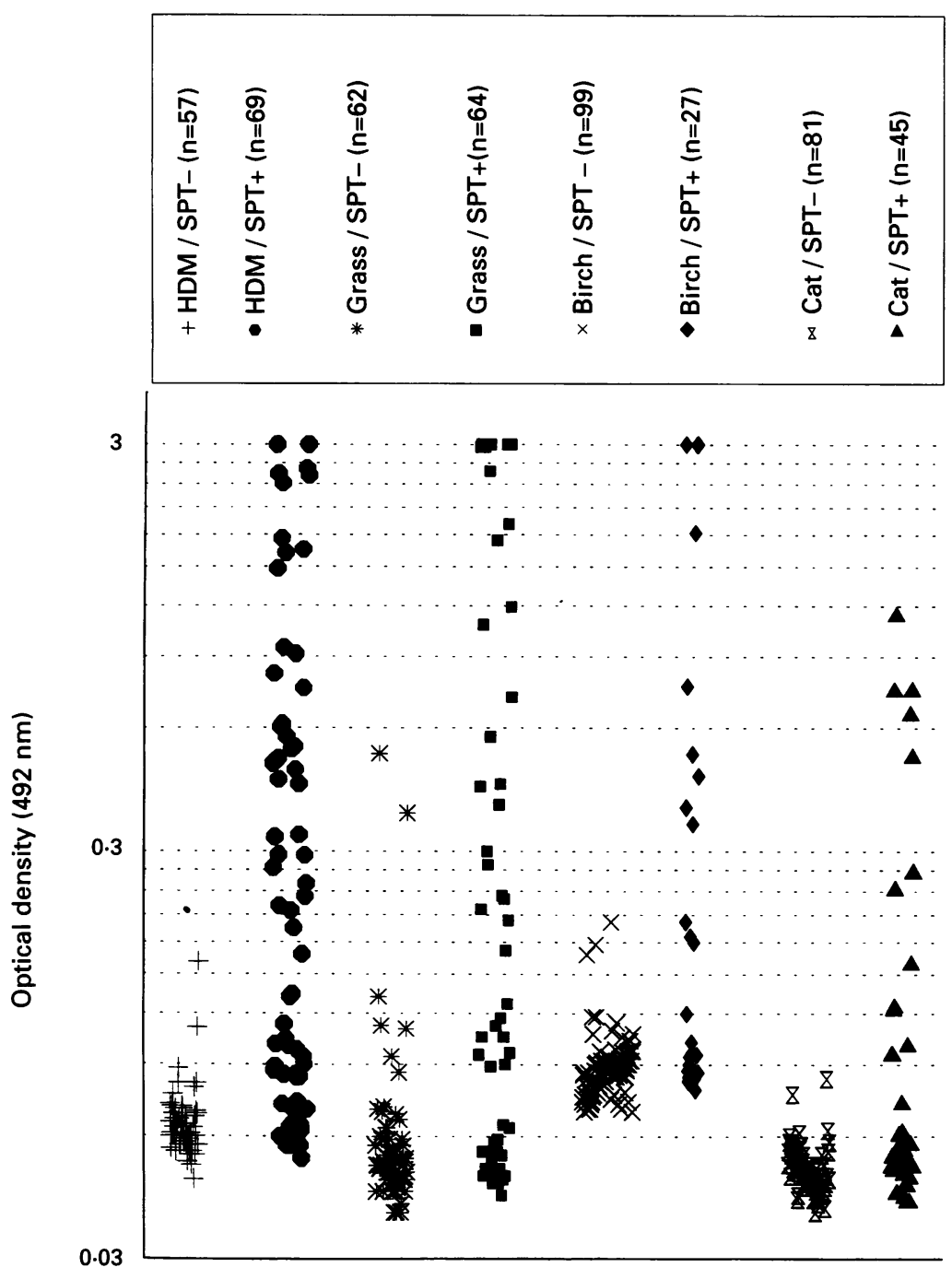

Figure $4 E L A$ for specific IgE to common allergens in serum samples from 126 bakery workers. Results are shown separately for subjects with a negative or positive skin prick test $(S P T)$ for the corresponding allergen. $H D M=$ house dust mite.

$10 \cdot 2 \%$, respectively, and a between day coefficient of variation of $6 \cdot 1 \%$. A series of 30 serum samples from laboratory animal workers, tested on two different days, with total IgE values ranging from 1.3 to $149 \mathrm{kU} / 1$, showed a mean coefficient of variation of $9.7 \%$ (SD $8 \cdot 2 \%$; range $0 \cdot 4 \%-26 \cdot 9 \%$ ).

Validation of the assay was accomplished by testing 156 serum samples of which the IgE content had been determined previously by

Table 2 Sensitivity and specificity of ELAs for anti-house dust mite, anti-grass pollen, anti-birch pollen, and anti-cat IgE compared with children and bakers positive to skin prick tests to the same allergens (based on the results shown in figs 3 and 4: numbers of positive skin prick tests in these populations of school children and bakery workers were: for house dust mite 25 and 69, for grass pollen 23 and 64, for birch pollen 4 and 27, and for cat 19 and 45)

\begin{tabular}{|c|c|c|c|c|c|}
\hline \multirow[b]{2}{*}{ Allergen } & \multirow[b]{2}{*}{ Threshold value ${ }^{\star}$} & \multicolumn{2}{|c|}{$\begin{array}{l}\text { School children } \\
(n=116)\end{array}$} & \multicolumn{2}{|c|}{$\begin{array}{l}\text { Bakery workers } \\
(n=126)\end{array}$} \\
\hline & & $\begin{array}{l}\text { Sensitvity } \\
(\%)\end{array}$ & $\begin{array}{l}\text { Specificity } \\
(\%)\end{array}$ & $\begin{array}{l}\text { Sensitvity } \\
(\%)\end{array}$ & $\begin{array}{l}\text { Specificity } \\
(\%)\end{array}$ \\
\hline House dust mite & $\begin{array}{l}\text { Low } \\
\text { High }\end{array}$ & $\begin{array}{l}92 \\
88\end{array}$ & $\begin{array}{l}78 \\
94\end{array}$ & $\begin{array}{l}81 \\
61\end{array}$ & $\begin{array}{l}63 \\
96\end{array}$ \\
\hline Grass pollen & $\begin{array}{l}\text { Low } \\
\text { High }\end{array}$ & $\begin{array}{l}100 \\
100\end{array}$ & $\begin{array}{l}85 \\
91\end{array}$ & $\begin{array}{l}67 \\
59\end{array}$ & $\begin{array}{l}78 \\
92\end{array}$ \\
\hline Birch pollen & $\begin{array}{l}\text { Low } \\
\text { High }\end{array}$ & $\begin{array}{l}100 \\
100\end{array}$ & $\begin{array}{l}90 \\
96\end{array}$ & $\begin{array}{l}48 \\
48\end{array}$ & $\begin{array}{l}97 \\
97\end{array}$ \\
\hline Cat & $\begin{array}{l}\text { Low } \\
\text { High }\end{array}$ & $\begin{array}{l}78 \\
68\end{array}$ & $\begin{array}{l}99 \\
99\end{array}$ & $\begin{array}{l}33 \\
27\end{array}$ & $\begin{array}{r}97 \\
100\end{array}$ \\
\hline
\end{tabular}

${ }^{\star}$ See footnote table 1 . radioimmunoasssay. ${ }^{16}$ Figure 2 shows a good correlation $\left(r^{2}=0.86\right)$ in the log transformed IgE concentrations, with a regression coefficient close to 1.0 and intercept zero, which means that absolute values of total serum $\mathrm{IgE}$ as found in our assay, and expressed in $\mathrm{kU} / \mathrm{l}$, were not systematically different from results obtained with other test methods.

SPECIFIC IgE TO COMMON ALLERGENS

Preliminary experiments with the various allergen preparations coated at neutral $\mathrm{pH}$ in so called high binding capacity polystyrene microtitre plates, and strongly positive serum samples from atopic patients, were performed to determine optimal assay conditions (not shown). For most allergen preparations a coating concentration of 1-5 $\mu \mathrm{g}$ per well was optimal. A standard coating concentration of 10 $\mu \mathrm{g} / \mathrm{ml}$ was chosen for house dust mite and grass pollen extracts, and $25 \mu \mathrm{g} / \mathrm{ml}$ for the tree pollen and cat allergen preparations. Anti-rat urine, anti-mouse urine and anti- $a$-amylase IgE assays were assessed with an allergen coating of $12.5 \mu \mathrm{g} / \mathrm{ml}$.

Optical density values of the reagent blanks were usually between 0.05 and 0.08 , with $S D<$ 0.01 , as determined in $\geqslant 10$ microplates on $\geqslant 4$ different days. Thus, with the mean optical density of the reagent blank +3 SDs (defined as already described) as the threshold value, optical density values as low as $0.07-0.08$ - for example, with an optical density (blank) of 0.05 with an SD of 0.007 -could frequently be interpreted as a positive $\mathrm{IgE}$ reaction. To diminish the risk of false positive reactions due to incidentally enhanced background reactions, we compared this criterion with another, more simple criterion, namely a threshold consisting of the mean optical density (blank) + $0 \cdot 05$. With both threshold levels, all negative serum allergen combinations were also negative in the second test, whereas with the lower threshold value a substantial number changed from positive to negative, particularly in the assay for anti-house dust mite IgE. This number was much lower, if the higher threshold value for a positive reaction was used (table 1).

Good correlations between skin prick test and EIA results for IgE were found. In the population of school children both sensitivity

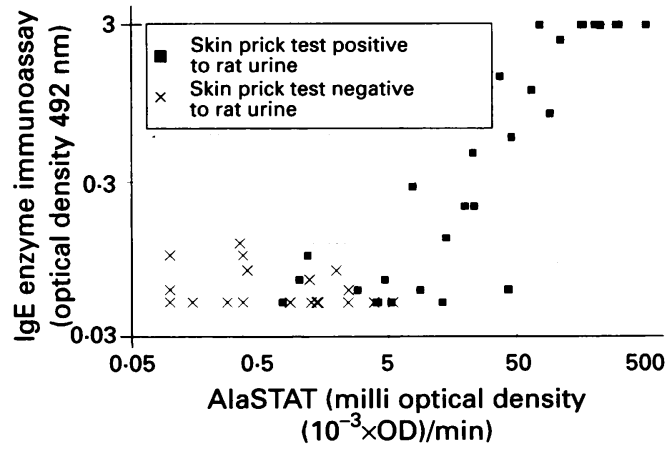

Figure 5 Comparison of the EIA for anti-rat urine IgE with the AlaSTAT assay. Serum samples from 52 laboratory animal workers with or without a positive skin prick test to rat urine were tested. 
Figure 6 Comparison of the ELA for IgE reacting with fungal $\alpha$-amylase, with the Phadezym RAST for the same antibodies. Serum samples from 32 bakery workers with or without a positive skin prick test reaction to the same allergen were tested.

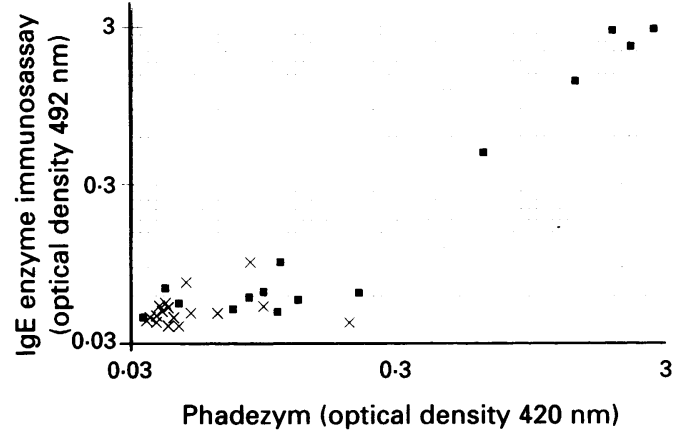

and specificity were remarkably high (fig 3), whereas in the population of bakers a generally high specificity was combined with a moderate or even poor sensitivity (fig 4). Table 2 shows that the choice of the optimal threshold level, providing maximal sensitivity and specificity for the skin prick test, seemed to depend on both the test allergen and the investigated population.

\section{IgE TO OCCUPATIONAL ALLERGENS}

The same EIA method could also be applied to identify subjects sensitised to occupational allergens. Thus, of 31 laboratory animal workers with a positive skin prick test for rat urinary proteins, 20 were positive in the EIA for IgE (optical density $>0 \cdot 1$ ) with a coating of the same allergen (fig 5), whereas only one of 21 skin prick test negative subjects showed a (weakly) positive in vitro IgE reaction. Figure 5 also shows that the EIA results correlated very well with those obtained with the AlaSTAT method for IgE anti-rat urinary protein, with a (Pearson) $r^{2}$ of 0.80 for the comparison of $\log$ transformed optical density values obtained with the serum samples from the 31 subjects positive in skin prick tests. For both in vitro assays-depending on the choice of the threshold value-a high specificity $(>90 \%)$ and a sensitivity of about $65 \%-70 \%$ were noted.

Similar results were obtained by comparing the EIA with the Phadezym RAST method in the measurement of IgE reacting with fungal $\alpha$-amylase (fig 6). Although both assays showed a relatively low sensitivity in detecting subjects positive in skin prick tests $(30 \%-35 \%)$, their specificity was $>90 \%$, and the results of the two in vitro assays were strongly correlated, both qualitatively and quantitatively. Thus, a (Pearson) $r^{2}$ of 0.92 was calculated for log transformed optical density values obtained with the serum samples of subjects positive in skin prick tests.

\section{Discussion}

Assessment of total serum IgE is usually included in routine IgE serology, as enhanced total $\mathrm{IgE}$-at least in populations with a low prevalence of helminthic infestation - can be a rather general marker of already existing atopy, or of an inherited atopic predisposition. Thus, total serum IgE may be of predictive value for the development of common or occupational allergic disease in cohort stud- ies. ${ }^{1013}$ In at least one large population study, the relation between the prevalence of asthma and total serum IgE was apparent over the whole range of IgE concentrations, ${ }^{13}$ which may point to the importance of accurate $\operatorname{IgE}$ measurements in clinically normal ranges, thus below 100-150 kU/1.

The EIA described here seems to meet these requirements. In general, sandwich EIAs should be performed with antibodies directed against different epitopes. In this particular case, however, the assay makes use of the symmetric structure of the IgE molecule, in that IgE antibodies are captured between two identical monoclonal antibodies-one coated to the microwells and one labelled with peroxidase-recognising an epitope in the $\mathrm{C}_{\mathrm{H}} 2$ domain of each $\mathrm{IgE} \mathrm{H}$ chain. ${ }^{18}$ The spatial structure of the $\mathrm{C}_{\mathrm{H}} 2$ domains in the $\operatorname{IgE} \mathrm{F}_{\mathrm{C}}$ region is apparently such that steric hindrance does not occur, and a detection limit of $0.05-0.1 \mathrm{kU} / 1$ - corresponding to about $0.1-0.2 \mathrm{ng} / \mathrm{ml}$-is reached. Thus, with our routine procedure serum IgE concentrations between 1 and 150-200 kU/l can be measured with high accuracy. In our experience until now, a second test-usually at higher serum dilutions, because of too strong reactions of the routinely applied serum dilutions-is indeed required for only $5 \%-10 \%$ of serum samples from random (control) populations, and for $10 \%-20 \%$ of serum samples from subjects who on the basis of a questionnaire are classified as cases because of the presence of respiratory symptoms. Retesting because of a difference of $>15 \%$ for total IgE values measured at different serum dilutions, is only incidentally required, usually because of technical failures.

More direct and specific assessment of atopy is provided by assays for allergen specific IgE. Most laboratories use commercially available test methods, which have been developed to meet the strong requirements for individual clinical diagnosis. The use of these assays in occupational or environmental epidemiological studies, however, has several disadvantages. Identification of unknown allergens in dust samples from the workplace or a dwelling's indoor environment may require a more flexible test system in which the allergen content-the presence of specific IgE binding components - of several dust samples can be easily tested. In such cases freshly prepared extracts from dust samples have to be immobilised on a carrier, and subsequently incubated with serum IgE antibodies of exposed subjects. Of the test systems already mentioned only the RAST method with activated, non-occupied discs can be used in this way, but even then the procedure is relatively laborious. Another major drawback might be the costs of the commercial kits, particularly when in population studies for each individual participant a complete IgE profile has to be obtained with a panel of occupational and common allergens.

Until now, application of EIA methods in $\operatorname{IgE}$ serology has been reported only incidentally. ${ }^{19-21}$ One reason might be the often com- 
plex, and sometimes variable, biochemical nature of allergen preparations, which may seriously affect the coating of the relevant allergen molecules to microtitre wells, and presentation of their epitopes for IgE binding. In our previous studies on anti-yeast $\operatorname{IgE}, 1415$ several types of microtitre plates and coating buffers had to be tested when optimising the method. Nevertheless, in our present studies most conventional microtitre plates and simple PBS as the coating buffer provided suitable test conditions for most common environmental and occupational allergens. Actually, we already used the same procedure for the assessment of $\operatorname{IgE}$ reacting with various other allergens, including pig urinary proteins, storage mite extracts, dog allergens, peanut and soy allergens, and also a low molecular weight component like chloramine- $T$, which was coupled to microwell coated human serum albumin, analogous to a previously described radioimmunoassay..$^{22}$

An obvious disadvantage of the EIAs for allergen specific IgE may be the lack of standardisation, which for the moment precludes a quantitative comparison of the results of EIA with different allergens, and thus expression of data in a units $/ \mathrm{ml}$ system as used in the various commercial test methods. At present we mainly use the results of our EIAs qualitatively, which in many population surveys may be sufficient to classify people as atopic or non-atopic, or as being reactive to a particular allergen. The routine procedure applied so far consists of testing on each day restricted numbers of serum samples (seven/plate) on plates with microwells coated with four to six different allergens. As a consequence, there is only one control well (reagent blank) per allergen and per plate, and SDs might on some days be very low $(<0.005)$. This may result in relatively high numbers of serum samples that according to the low threshold criterion (table 1) are regarded as positive. These serum samples will all be retested, together with a similar number of randomly chosen negative serum samples. In the second test, however, we used plates completely coated with one allergen, to test simultaneously all serum samples from a large series that have been positive for the same allergen in the first test, as found on different days. Thus in the second test series more reagent blanks (at least four to six per plate) are included, and the SD can be more reliably estimated. This might explain the lower prevalence of positive reactions in the second test (table 1). Another explanation might be regression to the mean, particularly in the case of anti-house dust mite IgE, in which many borderline reactions were found (figs 3 and 4).

The EIAs for IgE to the work related allergens rat urine and $\alpha$-amylase showed a good correlation with two commercially available test kits (figs 5 and 6). Although clearly below $100 \%$, these correlations are in the same order of magnitude as reported for comparisons of commercial test methods. ${ }^{23-27} \mathrm{~A}$ similar conclusion can be drawn for the comparison with results of skin prick tests (figs 3 and 4). For the children's population both sensitivity and specificity were remarkably high, such that the EIAs might be used as a full equivalent of the skin prick test. This would be an obvious advantage, if for some reason the atopic status of people has to be assessed retrospectively, in a study in which no skin prick test has been performed but serum samples have been collected and stored.

In the bakers' population the specificity of the EIA was also very good, whereas the sensitivity was considerably lower, varyingdepending on the chosen threshold levelfrom $27 \%-33 \%$ for cat allergen to $61 \%-81 \%$ for house dust mite allergens. These values might seem unacceptably low, compared with the usually reported $70 \%-90 \%$ for most allergens in studies comparing in vitro IgE assays with skin prick tests, ${ }^{23-27}$ although sensitivities as low as $50 \%$ are also found in some cases. Most reported studies are performed with test panels from clinical departments, in which serum samples from people with relatively strong in vivo and in vitro reactions might be overrepresented. In open populations the proportion of subjects with a weak and borderline reaction might be larger, and-assuming that in vitro assays are always less sensitive than the skin prick tests ${ }^{28}$ - this would result in a much lower sensitivity for in vitro assays in general. A better example might be found in previous studies on atopy among farmers. In such studies prevalences of positive skin prick tests for most common allergens were often two to threefold higher than for the corresponding RASTs. ${ }^{29}$ Other studies have shown that in adult populations the mean prevalences of positive RASTs or other in vitro IgE assays might be much lower than those of skin prick tests, ${ }^{30-33}$ thus implying a relatively low sensitivity-often below $50 \%$ - of the in vitro assays. The same and various other studies have shown a strong age dependency of both skin prick tests and specific serum IgE results, but with clearly different patterns. Thus, the prevalence of positive skin prick tests for most aeroallergens increases during childhood, remains relatively constant during the next decades, and declines after the age of 40-45..$^{31}$ In contrast, allergen specific as well as total IgE seem to be highest in childhood and show a notable decline after the age of $15-20 .{ }^{33}$ These patterns may completely explain the remarkable difference in sensitivity of the specific EIA for IgE in our children's and bakers' populations.

An important practical advantage of our $\mathrm{IgE}$ assays is their very low cost. Ordinary microtitre plates, conventional simple media, and highly diluted immune reagents are used, and the total costs per microtitre plate are less than $\$ 10$ and $\$ 14$ for the total and specific IgE assays, respectively. As in our routine procedures 20 serum samples can be tested for total $\operatorname{IgE}$ in one plate, and in the specific IgE assays seven serum samples can be tested in duplicate on a panel of six different allergens, the costs of such an IgE profile are less than $\$ 2.50$ per serum sample, which-at least in our experience-means an $80 \%-90 \%$ reduction of the costs compared with the use of commer- 
cially available test kits. Thus, we conclude that our EIA methods for measuring IgE might be very useful and cost effective tools in epidemiological studies on allergic diseases.

1 Chan-Yeung M, Malo JL. Aetiological agents in occupational asthma. Eur Respir F 1994; 7:346-71.

2 Hunskaar S, Fosse RT. Allergy to laboratory mice and rats: a review of the pathophysiology, epidemiology and clinical aspects. Lab Anim 1990;24:358-74.

3 Prichard MG, Ryan G, Walsh BJ, Musk AW. Skin test and RAST responses to wheat and common allergens and respiratory disease in bakers. Clin Allergy 1985;15: 203-10.

4 Sutton R, Skerritt JH, Baldo BA, Wrigley CW. The diversity of allergens involved in bakers' asthma. Clin Allergy 1984 14:93-107.

5 Venables KM, Upton J, Hawkins R, Tee RD, Longbottom J, Newman Taylor AJ. Smoking, atopy, and laboratory animal allergy. $\mathrm{Br} f$ Ind $\mathrm{Med}$ 1988;45:667-71.

6 Andersen I, Korsgaard J. Asthma and the indoor environment: assessment of the health implications of high indoor air humidity. Environ Int 1986;12:121-7.

7 Platts-Mills TAE, de Weck AL. Dust mite allergens and asthma - a worldwide problem. F Allergy Clin Immunol 1989;83:416-27.

8 Platts-Mills TAE, Ward GW, Sporik R, Gelber LE, Chapman MD, Heymann PW. Epidemiology of the relationship between exposure to indoor allergens an asthma. Int Arch Allergy Appl Immunol 1991;94:339-45.

9 Sporik R, Chapman M, Platts-Mills TAE. House dust mite exposure as a cause of asthma. Clin Exp Allergy 1992;22 897-906.

10 Wittig HJ, Belloit J, Filippi ID, Royal G. Age-related serum immunoglobulin $\mathrm{E}$ levels in healthy subjects and in patients with allergic disease. F Allergy Clin Immunol 1980;66:305-13.

11 Grundbacher FJ, Massie FS. Levels of immunoglobulin G, $\mathrm{M}, \mathrm{A}$, and $\mathrm{E}$ at various ages in allergic and non-allergic black and white individuals. $f$ Allergy Clin Immunol 1985;75:651-8.

12 Magnusson CGM. Cord serum IgE in relation to family history and as a predictor of atopic disease in early

13 Burrows B, Martinez FD, Halonen M, Barbee RA, Cline MG. Association of asthma with serum IgE levels and skin-test reactivity to allergens. $N$ Engl $\mathcal{F}$ Med 1989;320 271-7

14 Wessels MW, Doekes G, van Ieperen-van Dijk AG, Koers WJ, Young E. IgE antibodies to Pityrosporum ovale in atopic dermatitis. Br f Dermatol 1991;125:227-32.

15 Doekes G, van Ieperen-van Dijk AG. Allergens of Pityrosporum ovale and Candida albicans. I. Cross-reactivity of IgE-binding components. Allergy 1993;48:394-400.

16 Verhoeff AP, van Strien RT, van Wijnen JH, Brunekreef B. Damp housing and childhood respiratory symptoms: the role of sensitization to dust mites and moulds. Am $\mathcal{F}$ role of sensitization to dust

17 van Strien RT, Verhoeff AP, Brunekreef B, van Wijnen JH Mite antigen in house dust: relationship with different housing characteristics in the Netherlands. Clin Exp Allergy 1994;24:843-53.

18 Magnusson CGM, Aalberse RC, Johansson SGO. Monoclonal antibodies against human IgE. Identification of a determinant restricted to IgE of the lambda ligh chain type. Int Arch Allergy Appl Immunol 1986;80: 329-32.

19 Subba Rao PV, McCartney-Francis NL, Metcalfe DD. An avidin-biotin microEL ISA for rapid measurement of total and allergen-specific human IgE 7 Immunol Methods 1983;57:71-85.

20 Ponder RD, Stafford CT, Kiefer CR, Ford JL, Thompson WO, Hoffman DR. Development of an enzyme-linked immunosorbent assay for measurement of fire ant venom-specific IgE. Ann Allergy 1994;72:329-31.

21 Renstroem A, Malmberg P, Larsson K, Sundblad B-M Larsson PH. Prospective study of laboratory anima allergy: factors predisposing to sensitization and development of allergic symptoms. Allergy 1994;49: 548-52.

22 Kramps JA, van Toorenenbergen AW, van Vooren $\mathrm{PH}$, Dijkman JH. Occupational asthma due to inhalation of chloramine-T. Int Arch Allergy Appl Immunol 1981;64: 428-38.

23 Kelso J, Sodhi N, Gosselin VA, Yunginger JW. Diagnostic performance characteristics of the standard Phadebas performance characteristics of the standard Phadebas sus skin testing. Ann Allergy 1991;67:511-4.

24 Kleine-Tebbe J. Eickholt M Gatien M. Brunnee T O'Connor A, Kunkel G. Comparison between MAGIC LITE- and CAP-system: two automated specific IgE
LIT antibody assays. Clin Exp Allergy 1992;22:475-84.

25 Moneret-Vautrin D-A, Halpern GM, Brignon JJ, Nicola JP, Kanny G. Food specific IgE antibodies: a comparative study of AlaSTAT and Pharmacia RAST Phadebas CAP systems in 49 patients with food allergies. Ann Allergy 1993;71:107-14.

26 van Houte AJ, Bartels PCM. Comparative evaluation of the Pharmacia CAP system and the DPC AlaSTAT system for in vitro detection of allergen-specific IgE with the skin prick test. Eur $¥$ Clin Chem Clin Biochem 1992;30:101-5.

27 Agata H, Yomo A, Hanashiro Y, Muraki T, Kondo N, Ori T. Comparison of the MAST chemiluminescent assay system with RAST and skin tests in allergic children. Ann Allergy with RAST and

28 van der Zee JS, de Groot H, van Swieten P, Jansen HM Aalberse RC. Discrepancies between the skin test and IgE antibody assays: study of histamine release, complement activation in vitro, and occurrence of allergen-specific IgG. F Allergy Clin Immunol 1988;82:270-81.

29 Iversen $M$, Pedersen $B$. The prevalence of allergy in Danish farmers. Allergy 1990;45:347-53.

30 Halonen M, Barbee RA, Lebowitz MD, Burrows, B. An epidemiologic study of the interrelationships of total erum immunoglobulin $\mathrm{E}$, allergy skin-test reactivity, and eosinophilia. F Allergy Clin Immunol 1982;69:221-8.

31 Cline MG, Burrows B. Distribution of allergy in a population sample residing in Tucson, Arizona. Thorax 1989, 44:425-31.

32 Niemeijer NR, de Monchy JGR. Age-dependency of sensitization to aero-allergens in asthmatics. Allergy 1992;47: 431-5.

33 Omenaas E, Bakke P, Elsayed S, Hanoa R, Gulsvik A

Total and specific serum IgE levels in adults: relationship to sex, age and environmental factors. Clin Exp Allergy 1994;24:530-9.

\section{Vancouver style}

All manuscripts submitted to Occup Environ Med should conform to the uniform requirements for manuscripts submitted to biomedical journals (known as the Vancouver style.)

Occup Environ Med, together with many other international biomedical journals, has agreed to accept articles prepared in accordance with the Vancouver style. The style (described in full in the $B M \mathcal{F}, 24$ February $1979, p 532$ ) is intended to standardise requirements for authors.

References should be numbered consecutively in the order in which they are first mentioned in the text by Arabic numerals above the line on each occasion the reference is cited (Manson ${ }^{1}$ confirmed other reports $^{2-5}$. . .). In future references to papers submitted to Occup Environ Med should include: the names of all authors if there are seven or less or, if there are more, the first six followed by et al; the title of journal articles or book chapters; the titles of journals abbreviated according to the style of Index Medicus; and the first and final page numbers of the article or chapter. Titles not in Index Medicus should be given in full.

Examples of common forms of references are:

1 International Steering Committee of Medical Editors, Uniform requirements for manuscripts submitted to biomedical journals. $B r$ Med $\mathscr{f} 1979 ; 1: 532-5$.

2 Soter NA, Wasserman SI, Austen KF. Cold urticaria: release into the circulation of histamine and eosinophil chemotactic factor of anaphylaxis during cold phil chemotactic factor of anaphylaxis durit
challenge. N Engl f Med 1976;294:687-90.

3 Weinstein L, Swartz MN. Pathogenic properties of invading micro-organisms. In: Sodeman WA Jr, Sodeman WA, eds. Pathologic physiology, mechanisms of disease. Philadelphia: W B Saunders, 1974:457-72. 